\title{
Systems Analysis And Design: Using Experiential Projects To Enhance Learning
}

Daniel M. Ivancevich (Email: ivancevichd@uncwil.edu), University of North Carolina at Wilmington Susan H. Ivancevich (Email: ivancevichs@ uncwil.edu), University of North Carolina at Wilmington

\begin{abstract}
This paper provides accounting information systems instructors with an in-depth look at utilizing experiential learning field projects in a systems analysis and design course. Student groups were required to develop and implement fully functional systems for a real world client. We discuss project requirements, implementation issues, student feedback, and client feedback. Student and client perceptions of the experiential projects are favorable.
\end{abstract}

\subsection{Introduction}

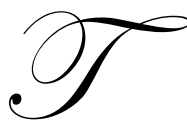

he purpose of this paper is to discuss the use of experiential learning projects in a graduate level Accounting Information Systems Analysis and Design course. Many universities are expanding the offerings of accounting information systems within their curricula. When expanding such offerings, it imperative that it be done in a manner cognizant of the calls for change in accounting education. Specifically, new courses should be developed in a manner that assists students in building critical thinking, teamwork, communication, and problem solving skills. Active learning opportunities, and more specifically experiential learning projects, are one means of meeting these goals.

Two prior studies have introduced experiential learning projects in the context of a separate consulting oriented course (Bryant 2001; Romney et al. 1993). Bryant (2001) provides guidelines on how to develop and administer an AIS consulting course. Romney et al. (1993) provides useful information on developing a consulting course targeted at MBA and non-systems focused Masters of Accountancy students. Both of these studies focus on experiential learning in a consulting context. Another study which focuses on experiential learning and accounting information systems is Zahn and Haroon (2002). This study focuses on the use of academic service learning projects tailored for not-for-profit organizations. Benefits for the students and university are descriptively discussed and points are raised regarding the community service aspect of such projects.

Our study focuses on implementing experiential concepts into the Systems Analysis and Design Course, a course required for systems focused Masters of Accountancy students. Our objective is to provide information on the application of experiential learning projects as a means of enhancing student understanding of systems analysis and design concepts. Knowledge of systems analysis and design concepts is important for students desiring to enter into systems areas of public accounting. Such knowledge also is imperative for 1) accountants needing to converse with IT personnel, 2) accountants and auditors who need to know there is a methodology for systems development and what that methodology is when assessing risk and developing audit plans, and 3) general accounting practitioners who find themselves working in an age where systems knowledge is an asset.

Our research provides five important contributions to the AIS literature. First, we extend the accounting information systems literature by specifically focusing on systems analysis and design activities. Second, we

Readers with comments or questions are encouraged to contact the authors via email. 
provide key details on the projects utilized in the course, including data needed and primary challenges. Third, we focus on implementation issues (including strategies for identifying prospective clients). Fourth, we include discussion of two years of systems analysis and design projects in our study. Finally, we provide data regarding student and client perceptions of their participation in the projects.

\subsection{Background in Active Learning \& Experiential Learning}

In 1990, the Accounting Education Change Commission (AECC) made recommendations that accounting education be changed to focus more on intellectual, communication, and interpersonal skill development within an active learning environment (AECC 1990). Within this context of active learning, the AECC specifically mandated that accounting graduates should be able to "locate, obtain, and organize information," "identify and solve unstructured problems in unfamiliar settings," "demonstrate effective reading, listening, writing, and speaking skills," and work effectively in groups (p. 307). The focus of active learning is on "doing" rather than on the "hearing and seeing" which serve as the mainstay of traditional lecture teaching methods (Specht and Sandlin 1991). It requires students to perform tasks and think about what they are doing rather than just listening to a speaker to receive information. Active learning requires students to take a participatory role rather than a passive role and generally affords students opportunities to develop and use higher-order thinking (such as critical thinking, analysis or evaluation), to be actively engaged in the activity, and/or to obtain quicker and greater feedback than students participating in passive learning (Bonwell, 1995). Hence, active learning involves much more than listening. Students must read, write, discuss, and/or solve problems, and most importantly, students must participate in higherorder cognitive tasks such as analysis, synthesis, and evaluation (Chickering and Gamson, 1987).

Active learning has been found to be a significant factor in student performance, student satisfaction, perceived quality of the educational experience, and perceptions of instructor effectiveness (Dickinson and O'Connell 1990; Nerenz and Knop 1982; Poppenhagen et al. 1982; Maher 1981). It is also identified as an essential factor in developing students' problem-solving abilities (Mayer 1989; Borthick 1996, 1998) and in enhancing cognitive development and achievement (Rutter 1985; Clark 1978). McKeachie et al. (1987) find that students involved in active learning obtain greater retention of material, have superior problem solving skills, and have better attitudes and higher motivation for future learning.

One type of active learning that can be utilized to meet the mandates of the AECC is experiential learning (Bradford and Peck, 1997). Experiential learning is generally recognized to mean involving students in a structured activity, encouraging discussion and integration of material learned, and then applying the principles learned to new situations (Specht and Sandlin 1991; Stanton et al. 1999). Service learning, internships, externships, practicums, case studies, field studies, simulations, and applied projects are each recognized as types of experiential learning (Washbourn 1996; Stanton et al. 1999).

While there are several theories relating to experiential learning (Argyris and Schon 1974, Walters and Marks 1981, and Kolb 1984), the most commonly cited theory is that of Kolb (Burns and Gentry 1998). According to Kolb $(1976,1984)$, experiential learning is achieved in settings where students may reflect on an experience or concept, relate it to theory, and then test it through application. More formally, Kolb (1984) asserts that in the experiential learning process, the participant moves progressively through the stages of (1) abstract conceptualization, (2) active experimentation, (3) concrete experience, and (4) reflective observation. In addition to the numerous benefits cited for active learning, experiential learning has also been found to lead to better retention by students than traditional lecture courses since most students find the experiential methods more enjoyable (Spencer and Van Eynde 1986; Van Eynde and Spencer 1988; Schadewald and Limberg 1990; Specht and Sandlin 1991).

Most experiential learning in accounting education has focused on the use of cases or simulations in a classroom setting (Borkowski and Welsh 1996; Campbell and Lewis 1991; Knechel 1992; Bradford and Peck 1997). Hermanson (1994) finds that active learning strategies appear to work well regardless of the complexity of accounting material or the cognitive ability of students. Because of the logistics involved, relatively few experiential 
learning exercises in accounting have involved students in applied field projects for real organizations. With a field project, student groups are asked to perform a task for an organization with the intent of making recommendations or developing a product from which the company may be able to derive benefits if successfully implemented.

The advantage of field projects over other methods is that the real world does not have to be simulated. Zlotkowki (1996) argues in-class learning activities have value, but that they can only approximate the intricacies of real world conditions. He asserts that direct practical experience provides the best tactic to help students to learn how to handle complex situations. Further, Albrecht and Sack (2001), in their discussion of the "perilous" state of accounting education, assert that the pedagogy in accounting education needs to be changed to allow students to obtain practical real world business experience through active learning opportunities such as internships, field studies, and service-learning assignments. Accounting information systems (AIS) oriented field projects help students understand the process of solving business problems through the design and implementation of information systems (Borthick 1998).

\subsection{Course Administration}

\subsection{Course Description}

The experiential course discussed in this study is the second course in a two-course sequence on accounting information systems analysis and design at a mid-sized regional state university. The two-course series is a required component of the Master's of Science in Accountancy (MSA) program for students electing a Systems/Audit focus within the program. ${ }^{1}$ The first course in the sequence is dedicated to coverage of the systems analysis and design methodologies and is presented in a traditional structured classroom format supplemented by case analysis. The second course builds on the topics covered in the first course by providing students the opportunity to apply systems analysis and design concepts to a real-world project.

\subsection{Student Demographics}

The experiential class was comprised of 18 MSA students in 2001 and 12 MSA students in 2002 in their third semester of graduate coursework. Student demographics are presented in Table 1. The typical student in this class was a 24 year old and entered the MSA program immediately after completing an undergraduate degree. The gender split of the class was relatively even with 13 females and 17 males.

\subsection{Project Identification and Assignment to Groups}

The projects were identified with the assistance of faculty colleagues, including one who operates a local CPA practice. Students were allowed to form their own groups, and projects were assigned to groups by the instructor. Over the two years of study, there were eleven different projects available for assignment, and these projects were associated with eight different organizations. Seven of the organizations involved were not-for-profit organizations (two national and five local), and the other organization was a closely-held corporation. Not-forprofit organizations are often eager to participate in these types of projects since they often find themselves in a position with high accounting and IT related needs, but face limited resources. Kahn and Haroon (2002) discuss the community service aspect of providing accounting information systems help to non-profit entities. The individual projects included financial reporting systems, database systems, and a market valuation system. More detail on specific projects is provided in the section 3 .

\footnotetext{
${ }^{1}$ Students within the MSA program elect to focus on one of two areas within the program. The two area of focus are Systems/Audit and Tax/Audit.
} 
TABLE 1: Student Demographics

\begin{tabular}{|l|ll|}
\hline Age & Median & 24.00 years \\
& Mean & 25.28 years \\
\hline Gender & Female & 13 \\
& Male & 17 \\
\hline Years of full-time employment: & & \\
Accounting & Median & 0.00 \\
& Mean & 1.43 \\
& & \\
Systems & Median & 0.00 \\
& Mean & 0.17 \\
Other & Median & 0.00 \\
& Mean & 1.61 \\
\hline Years of part-time employment: & & \\
Accounting & Median & 0.00 \\
& Mean & 0.51 \\
Systems & Median & 0.00 \\
& Mean & 0.07 \\
Other & & \\
& Median & 1.50 \\
Hours per week currently working: & Mean & 3.42 \\
\hline & Mean & 17.50 \\
& &
\end{tabular}

While our projects were identified with the assistance of faculty colleagues who know of organizations needing assistance, other methods of identification may also prove fruitful. Instructors may find success by inquiring within a small business or entrepreneurial center operating in the business school or university. Current and former students, and/or acquaintances may also know of companies or charities that may desire to participate in such projects. This course has been taught in an experiential manner for seven years and thus far, we have not found it difficult to identify organizations with an interest in participating in this type of experiential project. As a matter of fact, we often have to decline accepting projects because of a lack of student resources.

\subsection{Confidentiality Agreement}

A detailed waiver and confidentiality agreement was completed by each group of students. These agreements forbid students from divulging information about the client or from benefiting from the project in any way other than as an educational experience. Organizations were informed that they were participating in an experiential learning project that involved students and that the organizations were ultimately responsible for any decisions made to implement systems and/or recommendations. A copy of the confidentiality agreement is provided in Exhibit 1. 
EXHIBIT 1

\section{Confidentiality Agreement}

In consideration of participating in a systems development project for providing advice and assistance to a business, and thus receiving the increased educational experience that will result from said participation, I agree as follows:

(1) I agree that I will treat in strict and absolute confidence all information received by me from any business firm or person requesting assistance of any kind to be provided under this project. The only exception to this commitment will be in interactions with another member of my system development group and the course instructor.

(2) I agree that I will not recommend to any business firm or individual requesting assistance in the purchase of goods or services from sources in which I, or other members of the class, or sponsors may have a vested interest. Nor will I accept fees, commissions, gratuities or other benefits from any firm or individual I or any other member of the class may recommend to the business firm or individual so requesting assistance.

(3) I agree that I will not accept fees, commissions, gratuities or other benefits from any firm or individual for which I or any other member of the class may perform systems development activities on these educational experience projects.

(4) The client acknowledges that it is participating in an experiential course using students who are not experts. The role of the students is to develop a system, which subject to management approval, may be implemented at the organization. No warranties are made, express or implied, about the quality or functionality of the developed system. With respect to system functionality and implementation, the client agrees to hold harmless the students participating in the course, the course instructor, and the university.

Client:

Date:

Student Name:

Student Signature:

Student Name:

Student Signature:

Student Name:

Student Signature:

Faculty Signature:

(This document is to be signed in duplicate: Copy 1 for the client \& Copy 2 for permanent file) 


\subsection{Time Allocations}

The projects were completed by following the systems development life cycle (SDLC), a common systems analysis and design methodology. As shown in Table 2 Panel A, the greatest percentage of time spent by students in completing the project was on systems design (35.30\%), followed by systems planning/project management (34.33\%), systems analysis (17.00\%), and systems implementation $(13.37 \%)$. These percentage breakdowns may differ from the systems analysis and design research, but can be attributed to the relatively short window in which students had to complete their projects.

\subsection{Course Grading}

Grades were administered based on the quality and professionalism of the project and deliverables. Student grades were based on four components: 1) The organization and thoroughness of a project workbook, 2) the classroom presentation, 3) the quality of the system deliverables, and 4) group member assessment of individual performance.

\section{Project Workbook}

Student groups were required to maintain a project workbook detailing the project life cycle and all documentation and correspondence involving the group project. Typically, these workbooks were quite voluminous and contained such items as system prototypes, meeting notes, a training manual, all client correspondence, and other documentation.

\section{Presentations}

Student groups prepared 30-40 minute in-class Powerpoint presentations on the systems they had developed and implemented. One significant benefit of classroom presentations was that they gave other students the opportunity to learn about the projects of other student groups. Students were given the liberty to design their own presentation content and format so that they could focus the presentations on the points they deemed most relevant. All clients were invited to the classroom presentations; nine of the eleven project clients attended. Clients were also offered onsite presentations at their own organization; two clients requested this option.

\section{System Deliverables}

System deliverables included the system software developed for the client, systems documentation, and a training manual. Each of these items was presented to the client and reviewed with them as part of the implementation process.

\section{Performance Assessments}

Each group member was also asked to grade the other group members on a 0 to $100 \%$ scale. This grade was to reflect the contribution of each group member to the successful completion of the project.

\subsection{Project Details}

As discussed previously, course projects related to three very different areas: 1) financial systems, 2) database systems, and 3) valuation systems. The objective of each type of system varied significantly. These objectives are discussed below, followed by a discussion of logical and physical design issues common across all system types. Key goals, data requirements, and challenges for individual projects are discussed in more detail in Exhibit 2. 
TABLE 2: Project Completion Details

\begin{tabular}{|l|c|c|c|}
\hline & \multicolumn{3}{|c|}{ Percentage of Time Spent } \\
\hline \multicolumn{1}{|c|}{ Systems Development Life Cycle Component } & Median & Mean & Std Dev \\
\hline Systems Planning / Project Management (SP / PM) & $40.00 \%$ & $34.33 \%$ & $16.44 \%$ \\
\hline Systems Analysis (SA) & $17.50 \%$ & $17.00 \%$ & $8.54 \%$ \\
\hline Systems Design (SD) & $30.00 \%$ & $35.30 \%$ & $17.07 \%$ \\
\hline Systems Implementation (SI) & $10.00 \%$ & $13.37 \%$ & $11.06 \%$ \\
\hline
\end{tabular}

\subsection{Type of System}

\subsubsection{Financial Reporting}

The objective of the financial reporting systems was generally to produce a summary document of financial and non-financial information that could be used by the board of directors of the organizations at their monthly meetings. The boards of these organizations are typically unpaid volunteers who meet on average once a month for two hours to discuss a variety of issues, including the financial position of the organization. Since many board members lacked financial expertise, the financial systems ultimately needed to generate a one to two page summary of key information that would enable board members to focus on important issues without suffering information overload. To accomplish this task, the financial reporting system had to collect financial and non-financial data from various sources in the organization and condense and summarize the information in clear tabular and graphical form. The types of information disclosed in the reports differed based on the projects undertaken.

\subsubsection{Database}

The objective of most database projects was to develop a user-friendly database to track important information required for regulators and other key users. Typically, the databases included controlled data entry screens allowing only complete and consistent data to be entered into each field. A key goal of these projects was to capture all data in one place because most organizations found themselves with a combination of several different manual and computerized systems serving as data sources prior to the installation of the new systems. In several cases, the newly-developed databases cut reporting time down from days to minutes. One significant challenge encountered by groups developing databases was to understand the different regulatory requirements facing the organizations, so that proper information could be compiled. In some cases, these requirements could be quite extensive.

\subsubsection{Valuation}

The objective of the market valuation system was to develop a valuation model that would incorporate key performance and net worth data from different data sources into a comprehensive report calculating current market value estimates. In addition, the model impounded data from a 5-year proforma statement of cash flows, which also had to be developed and integrated into the market valuation model by the student group. The students had to study a variety of business valuations models, determine the strengths and weakness of each assumption, present findings to management, and adapt the developed model based on management feedback. 
Exhibit 2: Project Requirements

\begin{tabular}{|c|c|c|}
\hline Project & & Requirements \\
\hline $\begin{array}{l}\text { Financial Reporting Project } 1 \\
\text { (Local office of National Not-for- } \\
\text { Profit) }\end{array}$ & $\checkmark$ & $\begin{array}{l}\text { Goal: To create a financial reporting system detailing key financial } \\
\text { statement, budget, activity, and variance information to assist the Board } \\
\text { in decision making } \\
\text { Key Data: detailed financial and non-financial data on membership, } \\
\text { fundraising, grants, and health and service programs offered by the } \\
\text { organization } \\
\text { Biggest Challenge: Having to develop rudimentary systems to } \\
\text { efficiency convert manual data to a computerized system that could then } \\
\text { be used to upload data into the new financial reporting system. }\end{array}$ \\
\hline $\begin{array}{l}\text { Financial Reporting Project } 2 \\
\text { (Local Not-For-Profit) }\end{array}$ & $\checkmark$ & $\begin{array}{l}\text { Goal: To create an integrated financial reporting system drawing data } \\
\text { from } 10 \text { reports and } 3 \text { resale locations to produce a 2-page summary of } \\
\text { key information for Board use. } \\
\text { Key Data: revenue and expense information for } 3 \text { different resale } \\
\text { outlets, investment revenue, funds received from donations, county } \\
\text { funds, other not-for-profits, and government grants. } \\
\text { Biggest Challenge: Data conversion issues caused by a software change } \\
\text { made by the client during the system design process. }\end{array}$ \\
\hline $\begin{array}{l}\text { Financial Reporting Project } 3 \\
\text { (Local Not-For-Profit) }\end{array}$ & $\checkmark$ & $\begin{array}{l}\text { Goal: To provide a financial reporting system integrating data from } 3 \\
\text { separate reporting entities into a comprehensive set of key data for Board } \\
\text { use } \\
\text { Key Data: budgeted and actual revenues, expenses, cash collections } \\
\text { and disbursement for } 3 \text { separate but related entities (e.g., consignment } \\
\text { fees, travel costs, sales, meals, lodging \& entertainment, advance } \\
\text { collections, etc). } \\
\text { Biggest Challenge: Reconciling the data produced by } 3 \text { separate } \\
\text { systems which utilized different and incompatible software into one } \\
\text { comparative report }\end{array}$ \\
\hline
\end{tabular}




\begin{tabular}{|c|c|}
\hline Project & Requirements \\
\hline $\begin{array}{l}\text { Financial Reporting Project } 4 \\
\text { (Local office of National Not-for- } \\
\text { Profit) }\end{array}$ & $\begin{array}{l}\text { Goal: To produce a financial reporting system that condenses current } \\
\text { financial information from } 20 \text { pages of reports to an integrated report of } \\
\text { key data } 2 \text { pages in length. } \\
\checkmark \text { Key Data: condensed and segmented balance sheet and income } \\
\text { statement data including statistical indicators such as prior month/year } \\
\text { comparisons, actual versus budgeted data, available versus restricted } \\
\text { cash, and non-financial performance indicators related to membership } \\
\text { and program occupancy. } \\
\text { Biggest challenge: finding a way to concisely report segmented data on } \\
\text { individual fundraisers and programs while at the same time providing } \\
\text { condensed entity information and statistical indicators given the variety } \\
\text { of sources of data available, including manual data which had to be } \\
\text { converted prior to upload. }\end{array}$ \\
\hline $\begin{array}{l}\text { Financial Reporting Project } 5 \\
\text { (Local Not-for-Profit) }\end{array}$ & 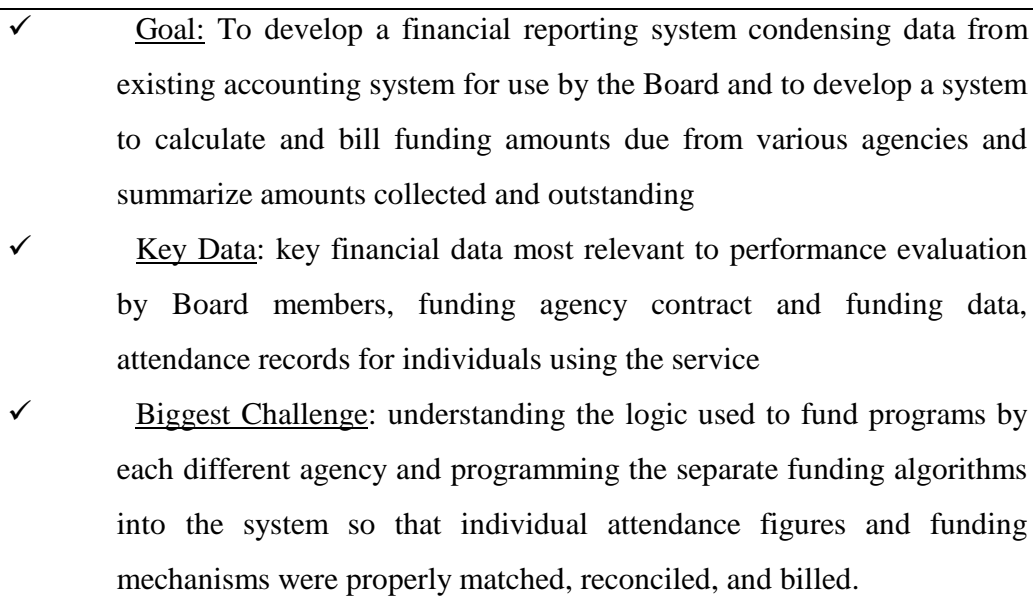 \\
\hline $\begin{array}{l}\text { Financial Reporting Project } 6 \\
\text { (Local Not-for-Profit) }\end{array}$ & $\begin{array}{l}\text { Goal: to develop a financial reporting system with adequate controls in } \\
\text { place to provide seamless continuity of treasury duties in light of } \\
\text { rotating volunteers serving in the role } \\
\text { Key Data: revenue, expense, asset and liability data for the company } \\
\text { including detailed data related to donated funds and services, taxes, } \\
\text { payroll data and filing information, and other key regulatory } \\
\text { requirements. } \\
\text { Biggest Challenge: successfully transitioning from a manual system to } \\
\text { a computerized system and building in proper controls to segregate } \\
\text { duties and control resources in an organization with limited resources. }\end{array}$ \\
\hline
\end{tabular}




\begin{tabular}{|c|c|}
\hline Project & Requirements \\
\hline $\begin{array}{l}\text { Database Project } 1 \\
\text { (Local Not-For-Profit) }\end{array}$ & $\begin{array}{l}\text { Goal: To develop a database system that would track services used } \\
\text { by clients in a more efficient manner than the manual systems } \\
\text { previously in use. } \\
\text { Key Data: manual data on individuals using the service, nature and } \\
\text { scope of services required, and dates of use } \\
\text { Biggest Challenge: Accommodating a change in scope mid-way } \\
\text { through systems design that refocused the main goal away from } \\
\text { tracking funding and toward tracking services used by clients. This } \\
\text { was exacerbated by the fact that much of the data needed for the } \\
\text { system was in manual form }\end{array}$ \\
\hline $\begin{array}{l}\text { Database Project } 2 \\
\text { (Local Not-For-Profit) }\end{array}$ & $\begin{array}{l}\text { Goal: To maintain and upgrade the system developed in Project } 1 \text { to } \\
\text { include more detailed client data, incorporate user friendly data entry } \\
\text { forms and automatic queries so that regulatory reporting requirements } \\
\text { could be met more efficiently on a monthly, quarterly, and annual } \\
\text { basis } \\
\underline{\text { Key Data: individual and aggregate client data including services }} \\
\text { used, dates of use } \\
\text { Biggest Challenge: Ensuring correct data was captured to meet } \\
\text { regulatory reporting requirements. }\end{array}$ \\
\hline $\begin{array}{l}\text { Database Project } 3 \\
\text { (Local Not-For-Profit) }\end{array}$ & $\begin{array}{l}\text { Goal: To develop a fixed asset tracking system to account for all } \\
\text { donated fixed assets in accordance with Department of Housing and } \\
\text { Urban Development grant requirements. } \\
\text { Key Data: asset identification numbers, acquisition date for donated } \\
\text { and purchased assets, description, donation site, fair value, date } \\
\text { retired, asset classification, sales price, transfer date and location of } \\
\text { transfer, as applicable } \\
\text { Biggest Challenge: Developing the proper forms and reports to } \\
\text { create an adequate paper trail for management and auditors so that } \\
\text { donated and purchased assets could be tracked by date, location, type } \\
\text { of asset, and other factors. }\end{array}$ \\
\hline
\end{tabular}




\begin{tabular}{|c|c|}
\hline Project & Requirements \\
\hline $\begin{array}{l}\text { Database Project } 4 \\
\text { (Local Not-For-Profit) }\end{array}$ & $\begin{array}{l}\text { Goal: To develop, design, and implement a system to track funding, } \\
\text { memberships, and adoptions and relinquishments } \\
\checkmark \quad \text { Key data: personal identification data for adopter, adoptee, } \\
\text { relinquisher, contact information, dates, funding amounts } \\
\text { Biggest Challenge: Pulling data from two separate places to populate } \\
\text { the new database system. Data had to be collected from a manual } \\
\text { system of records and from an old database file containing a limited } \\
\text { number of data fields and reconciled between the two prior to } \\
\text { inclusion in the new system. }\end{array}$ \\
\hline $\begin{array}{l}\text { Market Valuation Project } \\
\text { (Closely Held Corporation) }\end{array}$ & $\begin{array}{l}\text { Goal: To develop a system to be used to evaluate the value of the } \\
\text { business, as well as, a 5-year proforma cash flow template with "what } \\
\text { if" capabilities impounded in the template. } \\
\text { Key Data: monthly and annual sales and sales growth, annual change } \\
\text { in product costs, expense information, equity, inventory, depreciation, } \\
\text { goodwill, intangibles data } \\
\text { Biggest Challenge: The complexity of the valuation models used in } \\
\text { this project and the integration of the data necessary for these models. }\end{array}$ \\
\hline
\end{tabular}

\subsubsection{Logical and Physical Design Issues}

To identify the most important types of information, students met with board members, financial executives (typically at the treasurer level), parties responsible for regulatory compliance, and auditors. In addition to learning valuable interpersonal skills through their interactions with group members and client personnel, students received a dose of reality when they learned that things do not always go as planned - that sometimes they could not contact individuals because of scheduling conflicts, did not receive information in a timely fashion, and/or could not get needed information.

Once system requirements were determined, students designed the systems. Logical design was often a challenge, as students had to figure out how to integrate and obtain data from the various reporting systems used by the organizations, as well as how to present it in the most useful manner. Non-financial data further complicated the projects since it was generally located in a separate system and often maintained manually. In some cases, rudimentary systems had to be developed to convert the manual information to a computerized system, and then data from the computerized systems could be uploaded into the new system.

In terms of physical system design, most groups developing financial reporting systems used spreadsheet templates because of their ease of use in terms of both downloading data and custom formatting. Groups working on database development generally chose to use Access, given that most clients already had the software and the students had familiarity using it. The valuation project used a spreadsheet system for its physical design.

\subsection{Student Perceptions Of Experiential Learning Project}

At the completion of the project, students were surveyed to ascertain their perceptions of various attributes of the course and project. Specifically, students rated their agreement with statements about the experience using a 
zero to 10-point Likert scale, with 0 corresponding to "strongly disagree," 5 corresponding to "indifferent," and 10 corresponding to "strongly agree."

Table 3 includes a ranking of these statements based on mean and median strength of agreement. As shown in Table 3, student perceptions regarding the course and experiential project were quite favorable. All ratings exceeded eight on the Likert scale, indicating that the students generally agreed with each statement. As indicated in the table, the most highly rated factors related to the Systems Analysis and Design Project were that the students found the group experience appealing, enjoyed working on the project, found the project challenging, and strongly preferred the experiential course to a more traditional lecture style course (median response $=10$ ). The students also found the project interesting (median $=10.0$ ). All other factors also received strong agreement with a median rating of at least 9.0.

TABLE 3: Student Perceptions of Experiential Learning Project

\begin{tabular}{|c|c|c|c|}
\hline Student Questions & $\begin{array}{c}\text { Median* } \\
\mathbf{N}=\mathbf{3 0}\end{array}$ & $\begin{array}{l}\text { Mean* } \\
\mathrm{N}=30\end{array}$ & Std Dev \\
\hline \multicolumn{4}{|l|}{ GROUP WORK } \\
\hline My group worked well together & 10.00 & 9.60 & 0.89 \\
\hline $\begin{array}{l}\text { I learned more by working in a group than I would have } \\
\text { working alone }\end{array}$ & 10.00 & 9.33 & 1.56 \\
\hline My group shared the work fairly equally & 10.00 & 9.30 & 1.18 \\
\hline \multicolumn{4}{|l|}{ CLASS EXPERIENCE } \\
\hline $\begin{array}{l}\text { I prefer experiential classes like the Systems Design Project } \\
\text { to traditionally structured classes }\end{array}$ & 10.00 & 8.87 & 2.18 \\
\hline The Systems Design Project was challenging & 10.00 & 9.13 & 2.01 \\
\hline I enjoyed completing the Systems Design Project & 10.00 & 8.97 & 1.81 \\
\hline $\begin{array}{l}\text { I learned more working on the Systems Design Project than I } \\
\text { would have in an in-class lecture environment }\end{array}$ & 10.00 & 8.47 & 3.16 \\
\hline The Systems Design Project was interesting & 10.00 & 9.07 & 1.68 \\
\hline $\begin{array}{l}\text { The experiential Systems Design Project was beneficial to my } \\
\text { Information Systems education }\end{array}$ & 9.00 & 8.67 & 2.06 \\
\hline \multicolumn{4}{|l|}{ ANALYSIS AND DESIGN SKILLS } \\
\hline $\begin{array}{l}\text { Working on the Systems Design Project enhanced my skills } \\
\text { related to identifying deliverables }\end{array}$ & 9.00 & 9.20 & 0.81 \\
\hline $\begin{array}{l}\text { Working on the Systems Design Project enhanced my } \\
\text { understanding and ability to engage in prototyping }\end{array}$ & 9.00 & 9.13 & 0.94 \\
\hline $\begin{array}{l}\text { Working on the Systems Design Project enhanced my } \\
\text { understanding and ability to engage in physical system design }\end{array}$ & 9.00 & 8.77 & 2.10 \\
\hline
\end{tabular}




\begin{tabular}{|c|c|c|c|}
\hline $\begin{array}{l}\text { Working on the Systems Design Project enhanced my } \\
\text { understanding and ability to engage in logical system design }\end{array}$ & 9.00 & 8.57 & 1.89 \\
\hline $\begin{array}{l}\text { Systems Design Project improved my systems analysis and } \\
\text { design skills }\end{array}$ & 9.00 & 8.60 & 2.28 \\
\hline $\begin{array}{l}\text { Working on the Systems Design Project enhanced my ability } \\
\text { to determine system requirements }\end{array}$ & 9.00 & 8.80 & 1.21 \\
\hline $\begin{array}{l}\text { The Systems Design Project introduced me to important } \\
\text { systems analysis and design issues }\end{array}$ & 9.00 & 8.67 & 1.73 \\
\hline \multicolumn{4}{|l|}{ IMPLEMENTATION SKILLS } \\
\hline $\begin{array}{l}\text { Working on the Systems Design Project enhanced my } \\
\text { understanding and ability to prepare systems documentation }\end{array}$ & 9.00 & 8.77 & 1.43 \\
\hline $\begin{array}{l}\text { Working on the Systems Design Project enhanced my } \\
\text { understanding and ability to engage in system testing }\end{array}$ & 9.00 & 8.50 & 2.10 \\
\hline $\begin{array}{l}\text { Working on the Systems Design Project enhanced my } \\
\text { understanding of system training }\end{array}$ & 9.00 & 8.38 & 1.45 \\
\hline \multicolumn{4}{|l|}{ PROJECT MANAGEMENT SKILLS } \\
\hline $\begin{array}{l}\text { Working on the Systems Design Project enhanced my } \\
\text { understanding and ability to engage in project management } \\
\text { scheduling }\end{array}$ & 9.00 & 8.97 & 1.16 \\
\hline $\begin{array}{l}\text { Working on the Systems Design Project enhanced my } \\
\text { understanding of baseline project plans }\end{array}$ & 9.00 & 8.60 & 2.28 \\
\hline
\end{tabular}

Based on a Likert scale: $0=$ Strongly Disagree, $5=$ Indifferent, $10=$ Strongly Agree

Interestingly, the mean and median response varied substantially in several cases, due to low ratings of an isolated group. Problems with this group arose because of a change in project scope that arose mid-way through the development of the system. The students were frustrated by having to redesign the system because of an issue that should have been identified earlier in the process.

\subsection{Client Perceptions Of Experiential Learning Project}

Client perceptions were also measured with a zero to 10-point Likert scale, with 0 corresponding to "strongly disagree," 5 corresponding to "indifferent," and 10 corresponding to "strongly agree." Client perceptions of the project experience are presented in Table 4. Responses were received for nine of the eleven projects. Surveys were addressed to the individual who had the most project contact within the organization. As shown in Table 4, the clients were quite satisfied with the overall project experience, as all statements had a median response of nine or 10 indicating strong agreement. 


\section{TABLE 4: Client Perceptions of Experiential Learning Project}

\begin{tabular}{|c|c|c|c|}
\hline Client Questions & $\begin{array}{l}\text { Median* } \\
\mathrm{N}=9\end{array}$ & $\begin{array}{c}\text { Mean* } \\
\mathbf{N}=9\end{array}$ & Std Dev \\
\hline \multicolumn{4}{|l|}{ ORGANIZATIONAL BENEFITS } \\
\hline This project has been an overall good experience for the organization & 10.00 & 9.40 & 0.89 \\
\hline $\begin{array}{l}\text { The organization would be interested in participating in a student project } \\
\text { like the Systems Design Project again }\end{array}$ & 10.00 & 9.20 & 1.30 \\
\hline The organization plans to implement the project delivered in its entirety & 9.00 & 9.40 & 0.55 \\
\hline $\begin{array}{l}\text { Participating in the Systems Design Project was beneficial for the } \\
\text { organization }\end{array}$ & 9.00 & 9.20 & 0.84 \\
\hline $\begin{array}{l}\text { The focus of the project and its deliverable(s) helped to improve an } \\
\text { organizational weakness(es). }\end{array}$ & 9.00 & 8.80 & 1.64 \\
\hline $\begin{array}{l}\text { Implementation of the project deliverable(s) will improve effectiveness } \\
\text { and/or efficiency within the organization }\end{array}$ & 9.00 & 8.20 & 1.79 \\
\hline \multicolumn{4}{|l|}{ DELIVERABLES } \\
\hline Quality of project deliverables met expectations & 9.00 & 9.00 & 1.22 \\
\hline Project deliverables will be useful to the organization & 9.00 & 9.00 & 1.22 \\
\hline $\begin{array}{l}\text { The organization feels adequately prepared to use the deliverables } \\
\text { produced from the project }\end{array}$ & 9.00 & 8.00 & 2.00 \\
\hline \multicolumn{4}{|l|}{ INTERACTION WITH STUDENTS } \\
\hline On-site interaction with the student groups was a positive experience & 10.00 & 9.80 & 0.45 \\
\hline Students acted in a professional manner & 10.00 & 9.60 & 0.89 \\
\hline Students seemed knowledgeable and informed & 10.00 & 9.60 & 0.89 \\
\hline System training activities met expectations & 9.00 & 8.20 & 1.64 \\
\hline
\end{tabular}

* Based on a Likert scale: $0=$ Strongly Disagree, $5=$ Indifferent, $10=$ Strongly Agree

The highest ranking statements (sorted first on median and then on mean responses) were that the on-site interaction was positive, the students acted professionally, they were knowledgeable and informed, the overall experience was good for the organization, and the organization would be interested in participating in a similar project again. All other statements received a median response of nine.

\subsection{Recommendations for Conducting Effective Experiential Courses}

This particular experience with active learning pertains to a specific AIS course within our MSA curriculum. However, below we have identified some general recommendations for individuals who want to use experiential learning projects in any part of their curriculum. 


\subsection{Insist on Using a Well-Written Confidentiality Form and a Liability Waiver}

To help ensure proper conduct of students and appropriate expectations of client personnel, clearly document the experiential nature of the course. The clients should be reminded that 1) the students working on the projects are not considered experts, 2) implementation of deliverables and/or recommendations is a client responsibility based on their own expertise, and 3) the university, instructor, and students assume no responsibility for any potential problems. Be sure to obtain appropriate signatures from all involved parties. Also insist that students understand and sign confidentiality agreements to ensure that sensitive client data are kept secure.

\subsection{Empower Students To Take Ownership of the Project}

Our experience has taught us that too much guidance can be just as detrimental as not enough guidance. Students are generally much more capable than they think and can excel in an environment where they are gently guided in the right direction by the instructor when needed, but are encouraged to discover on their own the exact parameters and details of the project. If too much initial direction is provided, students may become too accustomed to this advice and fail to take full ownership of the project. We found it helpful to give students a general description of the project and encourage them to creatively address system development parameters on their own.

\subsection{Require Adequate Planning/Scheduling}

To ensure that the group has properly planned their time to meet the goals for project completion, require students to create a formal schedule including all phases of the project. The instructor should review this schedule to determine whether the students have a reasonable time frame for completing all of the project activities and provide feedback where necessary. Updates to these schedules will be required because time estimates seldom reflect the real world experience. Being introduced to ever-changing time frames is one of the beneficial products of this exercise, because students are given some experience in dealing with unexpected events.

\subsection{Require Mandatory Periodic Group Meetings}

The instructor should require all student groups to establish a periodic meeting time to discuss the progress of the projects with the instructor. This meeting time gives the instructor the opportunity to check on the progress of the project, help to derail any potential problems that may be developing, and to steer the groups back into the proper direction, if necessary. However, the instructor should be careful not to instruct the groups on what to do, but to instead limit comments to those that are only advisory in nature.

\subsection{Communicate with Clients}

Any time that real clients are involved with an experiential course, it is important that the instructor maintain contact with them to manage expectations, check on progress, and help to identify any problems from the client side of the experience. Doing so provides clients with reassurance that they have an instructor available to address questions or issues as they arise and before they become significant. Finally, such contact with the client can be a vital source of feedback with respect to the quality of the work being performed by the student groups for purposes of assigning grades.

\subsection{Clearly Identify to Whom the Groups Are Ultimately Responsible}

It is important that the instructor identify on the front end of the projects which party's needs are ultimately the most important. Since many of these projects may be set up with the assistance of individuals not associated directly with the course, it is important that the party with final authority on potential areas of conflict be specifically identified. In some cases, the individual assisting with the set up, the client or constituencies within the client, and the instructor may have different perceptions on the project scope. In order to avoid "scope creep" and to keep all parties satisfied, it is important to clearly identify whom the students should attempt to appease in situations of 
uncertainty. In the event of misunderstandings with the elements of the project, it is a good policy for the instructor to request a meeting with all interested parties to identify scope issues as soon as there appears to be a difference in opinion. Good communication is the key to handling these issues promptly and effectively.

\subsection{Pinpoint Deliverables Early in the Process}

As early as possible in the process, it is important to get all relevant parties to agree to the specific detailed services, products, and recommendations encompassed by the project. It is important to allow students adequate time to identify the specific requirements of the client, but once these requirements have been ascertained, all parties should agree to the exact deliverables to be provided to the client upon completion of the project.

It should be emphasized on the front end of the project that the timetable for completion is finite and that significant changes in client expectations might not be accommodated. Changes in project scope are difficult to accommodate when time is scarce, so it is important to get a consensus on project scope and deliverables as early as effectively possible.

\subsection{Remind Students to Think of Themselves as Consultants}

One of the key benefits of an experiential field project for both client and student is the opportunity to add value through innovative recommendations. Students should be encouraged to examine areas of client operations that could be run more efficiently or effectively within the scope of the project being performed. The client is generally quite pleased to have students act as "fresh eyes" and offer suggestions for operational improvement. Client satisfaction can be improved if the client feels students performed above expectations and offered useful suggestions. Hence, student groups should be encouraged to act as "consultants" and offer recommendations as one of the deliverables. However, ultimately it is up to the organization whether to implement the systems being developed and to act upon recommendations being made by student groups.

\subsection{Manage Students' Expectations of Real World Benefits and Issues}

Many students are so excited about having the opportunity to apply knowledge to a real world setting that they are surprised when things do not run as smoothly as planned. It is important to manage students' expectations by encouraging them to expect delays, experiences that do not "go by the book," and other frustrations. The same items that make an experiential field project exciting (dealing with issues outside of textbook theory, dealing with real world problems, working in groups, and experiencing the advantages and disadvantages of group dynamics) can also cause frustration. Students should be reminded that these small stumbling blocks are common occurrences in the real world and are only precursors of things to come when they eventually start their new careers. Further, students should be reminded that the ability to master these types of challenges is a skill that will set them apart from their peers in the workplace.

\subsection{Require Student Group Interaction Through Class Meetings and Presentations}

Client representatives should be invited to the in-class presentation, but students should also be encouraged to make a presentation to the client outside of class if the client deems this presentation to be beneficial. Instructors may also find it advantageous to obtain client feedback on the final presentation and deliverables to assist in assigning grades.

The instructor should require periodic meetings of the entire class, as well as a final in-class presentation. A benefit of requiring periodic meetings of the entire class and a final in-class presentation is that student groups can be exposed to the issues faced by other groups and how these issues were resolved. Further, classroom presentations may identify opportunities for future "real world" projects. 


\subsection{Limitations and Extensions}

This study is subject to several limitations. First, the study is intended to serve as an exploratory investigation into the use of experiential field projects in a systems analysis and design context. As such, the results presented relate to one course administered over two years by one instructor. Further, we addressed only one type of experiential learning, the experiential field project. With a small sample size and specific experiential context, the results of this study may not extend to other courses, instructors, or settings.

While the project discussed in this paper was conducted as a separate course, experiential projects can also be implemented as a component of an existing course. Future research in this area could focus on measuring the learning differentials of students involved in experiential learning projects versus those involved in more traditional types of courses, as well as differentiating among the benefits of various types of experiential learning opportunities, such as group field projects, simulations, and other active learning projects. Further research may provide more generalizable results as the number of courses, instructors, and contexts studied are expanded.

\subsection{Conclusions}

Our involvement with experiential learning projects has been invaluable. We have received favorable feedback from students, clients, university administrators, and the local press. Specifically, students perceived that their systems analysis and design skills, including such skills as identification of deliverables, prototyping, preparation of systems documentation, determination of system requirements, and logical and physical system design, were enhanced as a result of these projects. Students also indicated that they learned more in the "realworld" experiential course than they would have learned in a more traditional lecture environment. Clients indicated that the deliverables produced by the projects were of high quality, were useful for the organization, and would improve effectiveness and/or efficiency within the organization. Clients also indicated that the system design project was a positive experience for their organization and the projects delivered would be implemented to help the organization. We have not experienced any difficulty in obtaining clients interested in participating, and given the benefits of experiential learning, we plan to continue these types of projects into the indefinite future.

* The authors wish to thank Dana Hermanson, Roger Hermanson, Raquel Meyer Alexander, Dargan Frierson, Jr., Tom Baker, and Bill Compton, Ed Graham, and Ravija Badarinathi, for helpful suggestions on earlier drafts of this paper. Daniel Ivancevich would also like to thank KPMG for financial research support. Susan Ivancevich thanks Dixon Odom for financial research support.

\section{References}

1. Accounting Education Change Commission (AECC). 1990. Objectives Of Education For Accountants: Position Statement No. One. Issues in Accounting Education 5, 307-312.

2. Albrecht W.S., and R.J. Sack. 2001. The perilous future of accounting education. The CPA Journal (March): 16-23.

3. Argyris, C., and D. Schon. 1974. Theory in practice. San Francisco: Jossey-Bass.

4. Bonwell, C.C. 1995. Active Learning: Creating excitement in the classroom. Center for Teaching and Learning, St. Louis College of Pharmacy.

5. Borowski, S.C., and M.J. Welsh. 1996. 4MAT/formatting the accounting curriculum. Accounting Educators' Journal 8 (2): 67-90.

6. Borthick, F. 1996. Helping accountants learn to get the information managers want. Journal of Information Systems (Fall): 75-85.

7. Borthick, F. 1998. Transforming the AIS course: From an encyclopedic to an active learning approach. Change in Accounting Education: Implementation in Specific Accounting Courses and Subject Area: 95110.

8. Bradford, B.M., and M.W. Peck. 1997. Achieving AECC outcomes through the seven principles for good practice in undergraduate education. Journal of Education for Business (July/August): 364-368. 
9. Bryant, S.M. 2001. A blueprint for an AIS consulting course. Journal of Information Systems (Spring): 19-34.

10. Burns, A.C. and J.W. Gentry. 1998. Motivating students to engage in experiential learning: A tension-tolearn theory. Simulation \& Gaming (June) 133-142.

11. Campbell, J.E., and W.F. Lewis. 1991. Using cases in accounting classes. Issues in Accounting Education (Fall): 276-283.

12. Chickering, A.W., and Z.F. Gamson. 1987. Seven principles for good practice in undergraduate education. AAHE Bulletin 39,7 (March): 3-7.

13. Clark, A. 1978. Some implications of Piaget's work for the elementary teacher. Journal of Teaching and Learning (February): 2-12.

14. Dickinson, D., and D. O'Connell. 1990. Effect of quality and quantity of study on student grades. Journal of Education Research (March/April): 227-231.

15. Hermanson, D.R. 1994. The effect of self-generated elaboration on students' recall of tax and accounting material: Further evidence. Issues in Accounting Education (Fall): 301-318.

16. Kahn, Z., and M.M. Haroon. 2002. Academic service-learning in an accounting information systems capstone course. The Review of Business Information Systems (Fall): 93-100.

17. Knechel, W.R. 1992. Using the case method in accounting instruction. Issues in Accounting Education (Fall): 205-217.

18. Kolb, D.A. 1976. Management and the learning process. California Management Review (Spring): 2131 .

19. 1984. Experiential learning: Experience as the source of learning and development. Englewood, Cliffs, NJ: Prentice-Hall.

20. Maher, C. 1981. Training of managers in program planning and evaluation: Comparison of two approaches. Journal of Organizational Behavior Management (Spring): 45-56.

21. Mayer, R. 1989. Cognitive views of creativity: Creative teaching for creative learning. Contemporary Educational Psychology (July): 203-211.

22. McKeachie, W.J., P.R. Pintrich, Y. Lin, and D.A. Smith. 1987. Teaching and learning in the college classroom: A review of the research literature. Ann Arbor: Regents of the University of Michigan. ED 314 999, 1-124.

23. Nerenz, A., and C. Knop. 1982. A time-based approach to the study of teacher effectiveness. Modern Language Journal (Fall): 243-254.

24. Poppenhagen, B., E.Schuttenberg, and J. Gallagher. 1982. Active learning for post secondary educators: A study of two learning designs. Alternative Higher Education (Summer): 242-257.

25. Romney, M.B., J.O. Cherrington, and A. Knighton. 1993. Implementing a graduate management consulting course. Journal of Information Systems (Spring): 48-61.

26. Rutter, M. 1985. Family and school influences on cognitive development. Journal of Child Psychology and Psychiatry and Allied Disciplines (September): 683-704.

27. Schadewald, M., and S. Limberg. 1990. Instructor-provided versus student-generated explanations of tax rules: Effect on recall. Issues in Accounting Education (Spring): 30-40.

28. Specht, L.B., and P.K. Sandlin. 1991. The differential effects of experiential learning activities and traditional lecture classes in accounting. Simulation \& Gaming (June): 196-210.

29. Spencer, R.W., and D.F. Van Eynde. 1986. Experiential learning in economics. Journal of Economic Education (Fall): 289-294.

30. Stanton, T.K., D.E. Giles, and N.I. Crux. 1999. Service-learning: A movement's pioneers reflect on its origins, practice and future. San Francisco: Josey-Bass.

31. Van Eynde, D.F., and R.W. Spencer. 1988. Lecture versus experiential learning: Their differential effects on long-term memory. Organizational Behavior and Teaching Review 12: 52-58.

32. Walters, O.A., and T.E. Marks. 1981. Experiential learning and change. New York: John Wiley.

33. Washbourn, P. 1996. Experiential learning. Liberal Education (Summer): 10-15.

34. Zlotkowski, E. 1996. Opportunity for all: Linking service learning and business education. Journal of Business Ethics (January): 5-19. 